\title{
Insulin 分泌の神経性調節に関する研究
}

\author{
迷走神経の Insulin 分泌調節機構について
}

\author{
第 2 報 Insulin 分泌元進に及ぼす \\ 迷走神経切断の影響
}

\author{
東京大学医学部冲中内科教宣 \\ 井出健彦 \\ STUDIES ON THE ROLE OF THE VAGUS IN INSULIN SECRETION \\ PART II. EFFECT OF SECTION OF THE VAGUS ON THE \\ INDUCED AUGMENTATION OF INSULIN SECRETION \\ BY \\ Takehiko Ide \\ Okinaka Clinic, School of Medicine, Tokyo University
}

\begin{abstract}
梗概 迷走神経のInsulin 分泌調節の生理的意義を検討する日的で, 先に当教室で確認したブドウ棹， 綜合アミノ酸製剤及び生長ホルモン投与後化招来されるInsulin 分泌光進に対し，該神経切断が如何

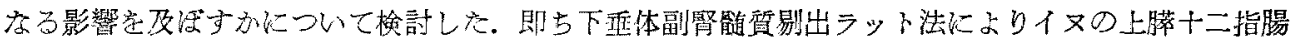
静脈血然 Insulin 濃度の変動を観察し次の成續老得た，1）ブドウ糖，綜合アミノ酸製郕及び生長木

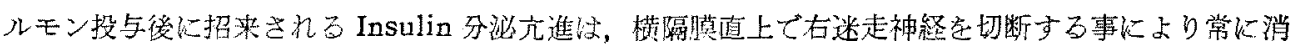

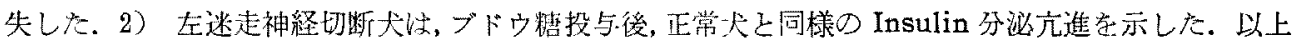
の成績より，右迷走神経は，乙机らのInsulin 分泌立進の招来に際し不可欠であり，Insulin 分泌調

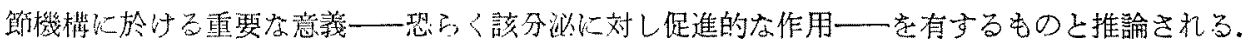

\section{緒言}

迷走神経の Insulin 分泌調節機精を梌穼するに 洒たり，前報において著者は，当教空小坂らの下

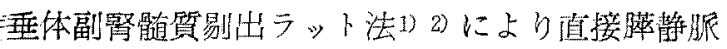

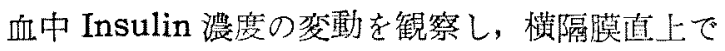
轩断した右侧（背側）迷走神経末梢端の電気刺激 が一過性に著明な Insulin 分泌の克進を惹起する 事を確認した。この成績は，右側迷走神経が生体 に起こる或る種の条件下に扔いては，Insulinの 分泌直進をうながす可能性を示峻するものと考え
られる。このような見解から，本報においては、迷 走神経の Insulin 分必调節の生理的意義に関し検 討を行なう目的で，先に当教空において荤静脈血 中 Insulin 濃度を測定する事により確認したブド ウ綪3)，綜合アミノ酸製剂4)攻び生長ホルモン5) 投与後に催起される追加的 Insulin 分泌充進に対。 し，該神経の切断が如何なる影響を及改すかにつ いて検索した成績を報告する。

\section{実験方法}

1）迷走神経の切断 
約18時間緦食せしめた体重 $10 \mathrm{~kg}$ 前後の成大（雄 又は雌）にチオペンタールナトリウム（ラボナー ル）静脈内麻酔*を施した後開腹し, 右㑡(背側) 又は左側（腹側）の迷走神経の横隔膜直上部を腹 腔内に率引露出して切断した。

2）ブドウ糖，綜合アミノ酸製戍及び生長ホル モン投与.

(a) 体重 $1 \mathrm{~kg}$ 当り $1 \mathrm{~g}$ のブドウ綪を $2 \%$ 水溶 液となし，股静脈より 3 分間で注人した。時間的 経過の記録に際しては，注入開始 5 分後を以て 0 分とした。

(b) 総空素量 12１3\%の綜合アミノ酸製剂 (ポリタミン) 体重 $1 \mathrm{~kg}$ 当り $3 \mathrm{ml}$ を，10分間加け て股静脈内に注入した。注入開始時を０分として 時間的経過を記録した。

(c) 体重 $1 \mathrm{~kg}$ 当り $3 \mathrm{mg} の$ 生長ホルモン (Lot. No.：O-STH-4）を $10 \mathrm{ml}$ の生理食塩水に溶解， 腰部筋府内に注射した．注射時を 0 分として時間 的経過を記録した。

3）膵静脈血中 Insulin 濃度並びに末梢血糖值 の測定

上膵十二指腸静脈の苹藏からの出口附近を露出 し，少量のへパリンナトリウム溶液を添加した注 射筒により，適時 15 乃至 $20 \mathrm{ml}$ ゔつ採血，直ちに 血嶈を遠沈分離して，血漿 Insulin 濃度を下垂体 副腎髓質剔出ラット法1)2)により测定した。

同時に耳静脈血を埰取して，血糖值を Hagedorn-Jensen 法により測定した。

\section{実験成績}

（A）プド糖投与後の Insulin 分泌充進に及 ほすす迷走神経切断の影䇾

1) 対照群

5 例の正常犬について観察した上荤十二指腸静 脈血嶈 Insulin 濃度は,ブドウ糖投与後, 全例共辢 次上昇し，血糖が投与前值に回復した 120 分に最 高值を示し，以後比較的速かに下降した（表 1 ，

* $0.5 \mathrm{~g}$ を $20 \mathrm{ml}$ の蒸留水に溶解し, 初めにその半 量を注射し，残りを適時分割追加した。
図 1 ).

2）右迷走神経切断群

(i) ブドウ糖投与の約60分前に右側迷走神経 を切断した 3 例の上蓃十二指腸静脈血留 Insulin 濃度は,非切断対炤群の如き上昇を示すことなく， 終始投与前值附近に留まつた（表 $2 A$ ，図2). 及, 右迷走神経の切断後17日及び32日を経過して からブドウ糖投与を行なつた 2 例に抒いても，睟 静脈血中 Insulin 濃度は上昇を示さなかつた（表 $2 \mathrm{~B}$, 図 3 ).

(ii）ブドウ粕投与後, Insulin 分泌古進の確認 された60分及び90分において，おのおの右迷走神 経の切断を行なつた 2 例の膵静脈血中 Insulin 漫 度は，該切断により直ちにその増加過程を中断し て急速に投与前值に下降し，以後認むべき変動を

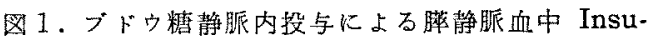

lin 整度及び末梢血糖值の变動一正常犬の成績

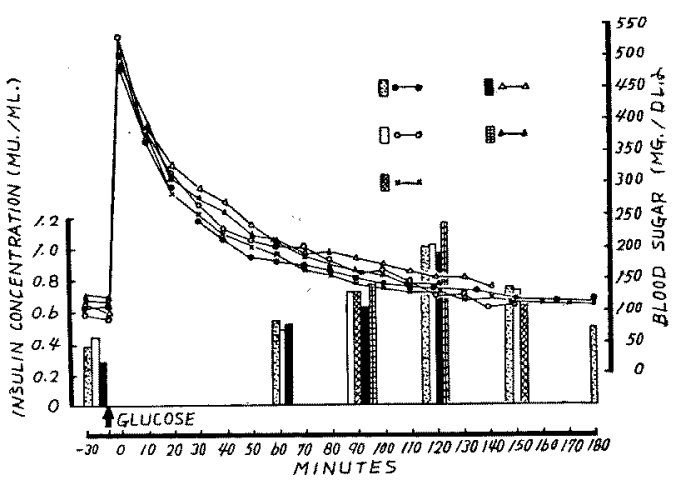

図2、ブドウ糖静眽内投与に上る膵静脈血中 Insulin 涉度及び末梢血精値の变動一右迷走神経切 断犬の成績 (1)ブトゥ糖投与60分前切断例

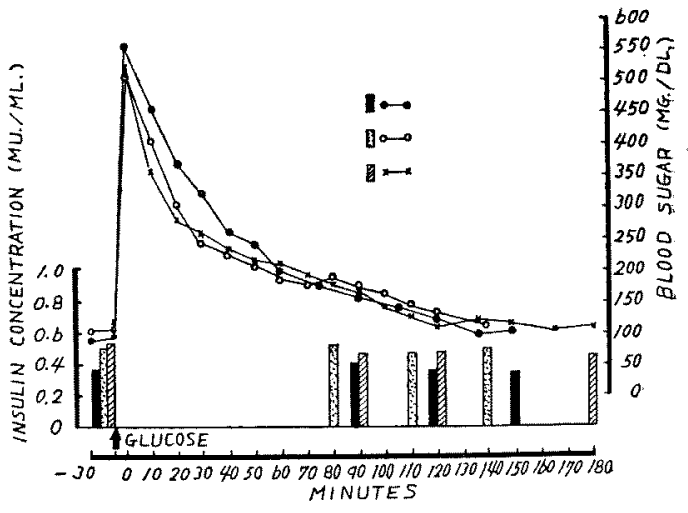




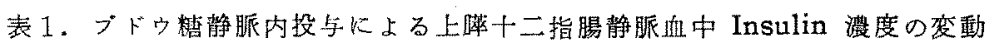

\begin{tabular}{|c|c|c|c|c|c|c|}
\hline \multirow{3}{*}{ 例 } & \multicolumn{6}{|c|}{ Insulin 浱 度 $(\mathrm{mu} / \mathrm{ml})$} \\
\hline & \multirow{2}{*}{ 投与前 } & \multicolumn{2}{|r|}{ 投 } & \multicolumn{2}{|c|}{ 後 （分） } & \\
\hline & & 60 & 90 & 120 & 150 & 180 \\
\hline No. 12 & 0.38 & 0.54 & - & 1.00 & 0.75 & 0.50 \\
\hline No. 13 & 0.44 & 0.48 & 0.72 & 1.05 & 0.74 & - \\
\hline No. 14 & - & - & 0.72 & - & 0.65 & - \\
\hline No. 15 & 0.28 & 0.51 & 0.62 & 0.96 & - & - \\
\hline No. 16 & - & - & 0.76 & 1.15 & - & - \\
\hline
\end{tabular}

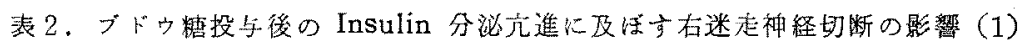
——ブド䋧投与前に招ける右迷走神経の切断

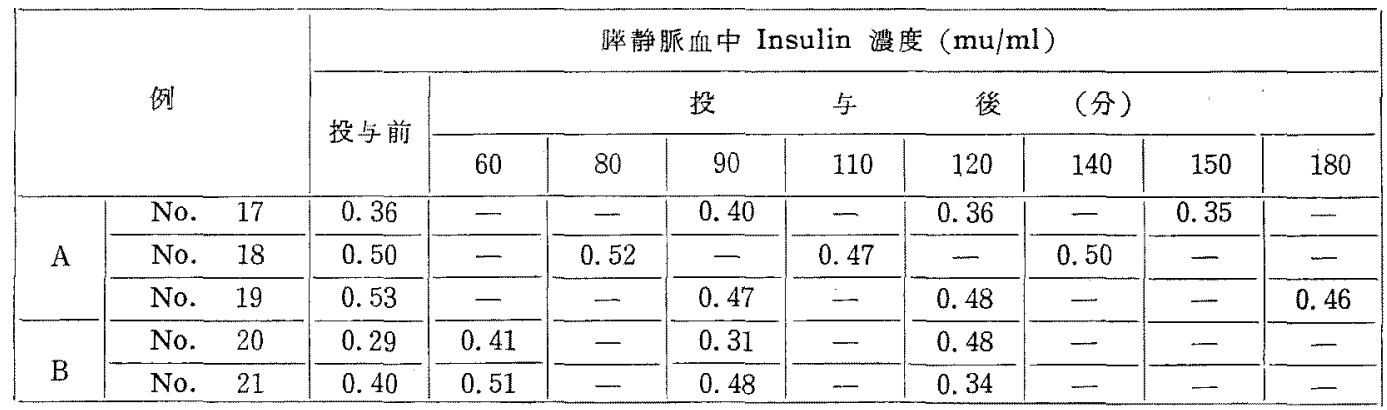

A 迷走神経切断60分後ブドウ糖投守例

B 迷走神経切断17日後 (No. 20) 及び32日後（No.21）ブドウ絋投与例

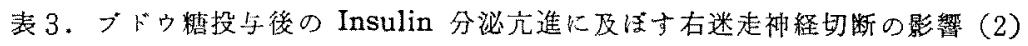

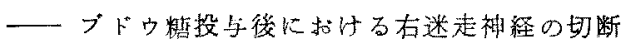

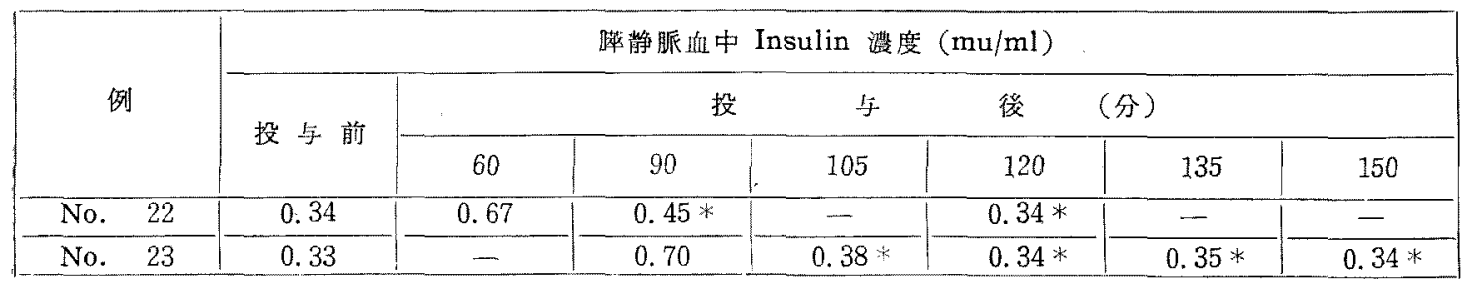

No. 22 ブドゥ綟投与 60 分後迷走神経切断例 No. 23 ブドゥ綟投与 90 分後迷走神経切断例 * 迷走神経切断後の Insulin 湍度

示さなからた（表 3, 図4）。

3）左迷走神経切断群

ブドウ糖投与前約 60 分に左迷走神経を切断した 2 例は, 非切断犬上同様，120分最高とする Insulin 分泌の充進を示した（表4, 四5).
対照群と各迷走神経切断群との栯同化伷線は相 似し，各群に特異な傾问を認め得なかつた（図 1 $\sim 5$ ).

（B）綜合アミノ酸製削投与後の Insulin 分泌 兄進に区代す右迷走神経切断の影響 


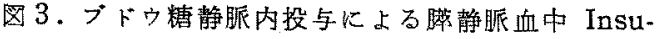
lin 警度及び末梢血糖值の変動一右迷起神経切 断犬の成績( 2) ブドゥ糖投与17日前(No. 20) 及び32日前 (No. 21) 切断例

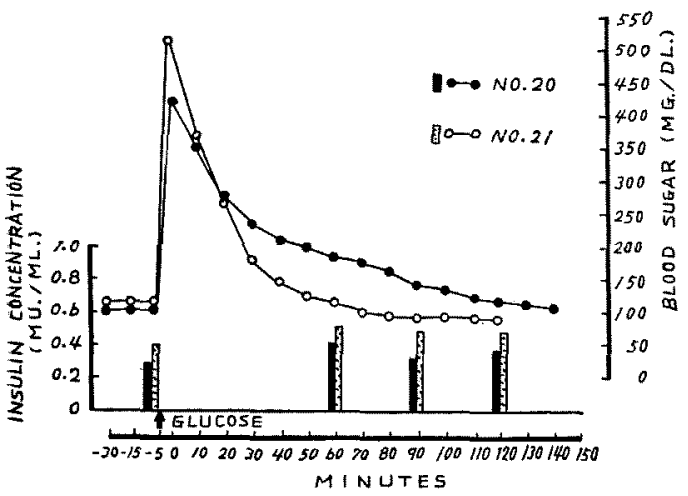

図 4.ブドウ糖静脈内投与に上る缕摰脈血中 Insulin 惯度及び末梢血䊰值の変動一右迷走神释切 断犬の成繢（3）ブドウ糖投与90分後切断例

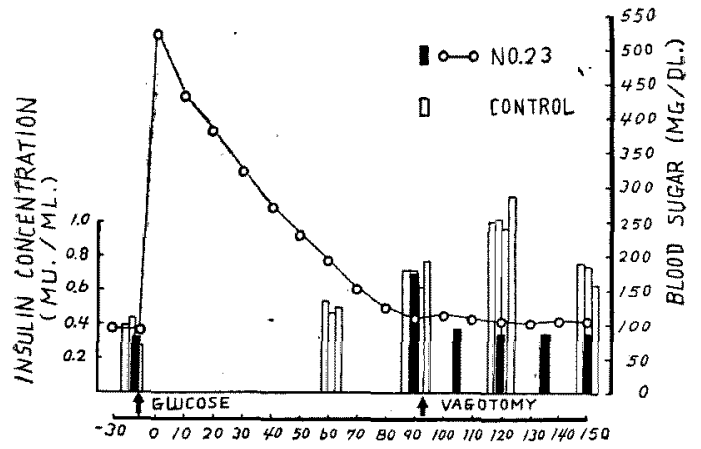

1) 対脆群

正常犬の上膵十二指腸静脈の血等 Insulin 湸庭 は，綜合アミノ酸製剂投与後 4 㭙間を最高值とす る上暈宗した（表 5，図6）。

2）右迷走神経切断群

綜合アミノ酸製用投与の60分前に在迷起神経を
図 5.ブドウ精静脈内投与による睟静脈血中 Insulin 溊度及び末梢血糖值の变政一左迷走神経切 断大の成維

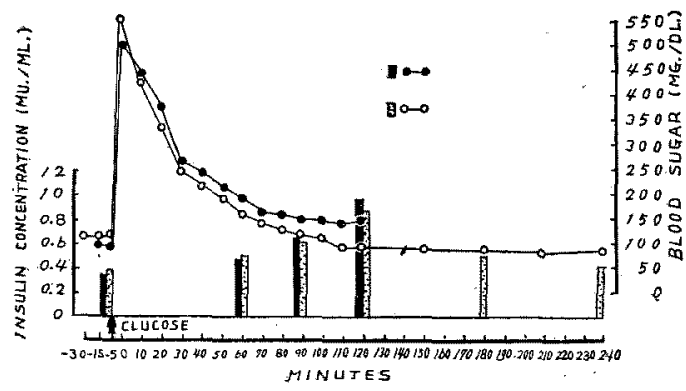

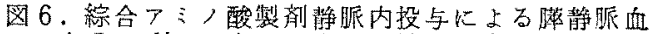
中 Insulin 濒度攻び末梢血糖值の变動一正常犬 の成績

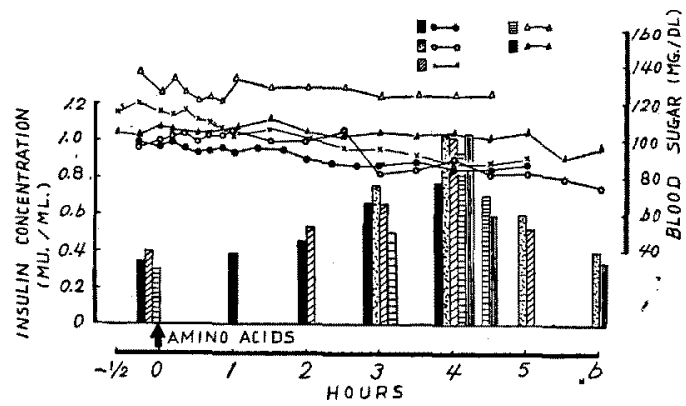

图 7. 綜合アミノ酸製剂静脈内投与による脺静眽血

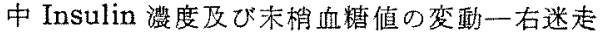
神释切断犬の成䌑

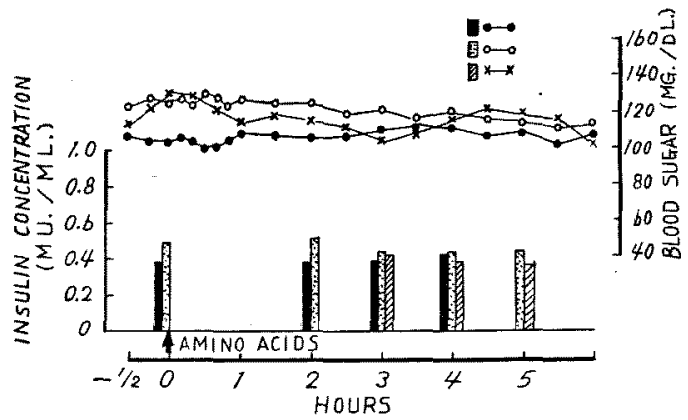

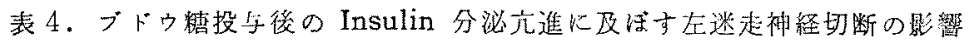

\begin{tabular}{|c|c|c|c|c|c|c|}
\hline \multirow{3}{*}{ 例 } & \multicolumn{6}{|c|}{ 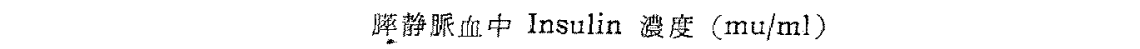 } \\
\hline & \multirow{2}{*}{ 投 与前 } & \multicolumn{2}{|r|}{ 投 } & 後 & \multicolumn{2}{|l|}{ (分) } \\
\hline & & 60 & 90 & 120 & 180 & 240 \\
\hline No. 24 & 0.35 & 0.48 & 0.69 & 0.97 & - & - \\
\hline No. 25 & 0.39 & 0.50 & 0.63 & 0.87 & 0.51 & 0.41 \\
\hline
\end{tabular}


表 5. 綜合アミノ酸製郕投与後のInsulin 分泌克進に及洼す右迷走神経切断の影響

\begin{tabular}{|c|c|c|c|c|c|c|c|c|c|c|}
\hline \multirow{3}{*}{, } & & & \multicolumn{8}{|c|}{ 膵静脈血中 Insulin 䟴度 $(\mathrm{mu} / \mathrm{ml})$} \\
\hline & \multirow{2}{*}{\multicolumn{2}{|c|}{ 例 }} & \multirow{2}{*}{ 投与 前 } & \multicolumn{3}{|c|}{ 投 } & 後 & \multicolumn{2}{|c|}{ （时間） } & \\
\hline & & & & 1 & 2 & 3 & 4 & $41 / 2$ & 5 & 6 \\
\hline \multirow{5}{*}{ 利绍例 } & No & 26 & 0.34 & 0.38 & 0.45 & 0.66 & 0.77 & - & 二 & - \\
\hline & No & 27 & 一 & - & - & 0.75 & 1.15 & - & 0.60 & 0.40 \\
\hline & No & 28 & 0.40 & 一 & 0.53 & 0.65 & 1. 10 & - & 0.52 & 一 \\
\hline & No & 29 & 0.30 & - & 一 & 0.50 & 0.93 & 0.70 & - & 一 \\
\hline & No & 30 & - & - & - & - & 1.15 & 0.59 & - & 0.34 \\
\hline \multirow{3}{*}{$\begin{array}{l}\text { 右迷走 } \\
\text { 神経 } \\
\text { 切断例 }\end{array}$} & No & 31 & 0.38 & - & 0.38 & 0.39 & 0.42 & - & - & - \\
\hline & No & 32 & 0.49 & - & 0.51 & 0.44 & 0.43 & - & $0 . \overline{43}$ & - \\
\hline & No & 33 & - & - & - & 0.42 & 0.38 & - & 0.37 & - \\
\hline
\end{tabular}

敖 6. 生長ホルモン投与後の Insulin 分泌元進に及活す右迷走神経切断の影響

\begin{tabular}{|c|c|c|c|c|c|c|c|c|c|c|c|}
\hline \multirow{3}{*}{ 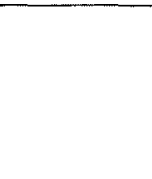 } & \multirow{3}{*}{ 例 } & & \multicolumn{9}{|c|}{ 洴静脈血中 Insulin 灙度 $(\mathrm{mu} / \mathrm{ml})$} \\
\hline & & & \multirow{2}{*}{ 投与前 } & \multicolumn{3}{|c|}{ 投 } & 与 & 後 & \multicolumn{3}{|c|}{ (時間) } \\
\hline & & & & $1 / 2$ & 1 & 2 & 3 & $\begin{array}{ll}31 / 4 \\
\end{array}$ & 4 & $41 / 2$ & 6 \\
\hline \multirow{3}{*}{ 対照例 } & No & & 0.35 & - & 3.20 & 2.10 & - & 1.80 & - & 0.76 & 0.31 \\
\hline & & 35 & - & 1.74 & 2.40 & 1.85 & - & - & - & - & - \\
\hline & No & 36 & - & 2.35 & - & - & - & 1.50 & - & 0.48 & - \\
\hline \multirow{2}{*}{$\begin{array}{l}\text { 右迷走神 } \\
\text { 䃽切断斤例 }\end{array}$} & No & 37 & 0.43 & 0.43 & 0.46 & 0.45 & 0.42 & - & - & - & - \\
\hline & No & 38 & - & - & 0.30 & 0.32 & 0.29 & - & 0.30 & - & - \\
\hline
\end{tabular}

切泚した 3 例の䐙静脈血等 Insulin 濃度は，投与 後著変を示さず, 対照群の如き Insulin 分泌兄進 は認められなかつた（表 5 ，园7）。

対然群並ぴに右迷走神経切断群とも，綜合アミ ノ酸製偊の投与後には，末梢近糖值の特異な変動 傾向学認め得なかつた（因 6，7）。

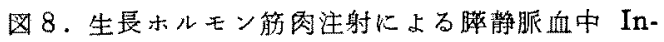

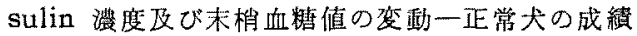

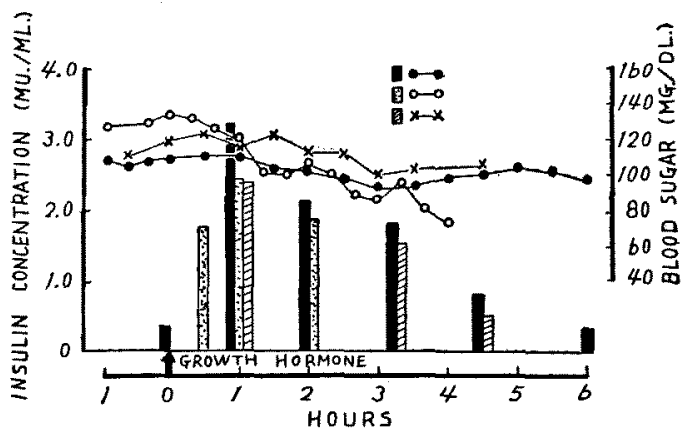

(C) 生長ホルモン投与後の Insulin 分泌六進 に及浪す右迷走神経切断の影響

1) 対炤群

生長ホルモン投与後, 㬸静脈血墏 Insulin 濃度

図 9.生長ホルモン筋肉注射に上る䑏静脈血中 Insulin 浀度及び末梢血糖值の変動一右迷走神経 切断犬の成績

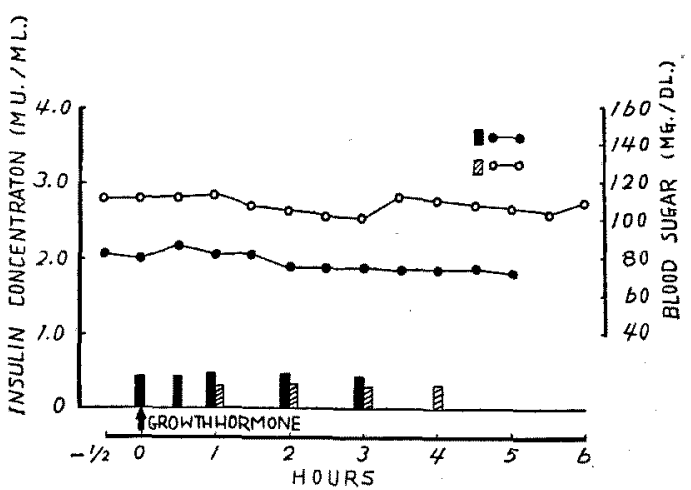


は，速かに著しい上昇を示し，投与後 1 時閒には 投与前の約10倍の最高值に達し，擞時間で漸次投 与前值附近まで下降した（表 $6 ，$ 図 8).

2）右側迷走神経切断群

生長ホルモン投与前 1 時間に右迷走神経を切断 した 2 例は, 対唯群の如き荤静脈血中 Insulin 濃 度の上昇を示军事なく，終始投与前值附近に留ま つた(表6, 図9).

対照群並びに右側迷走神経切断群の末梢血楉值 は，生長ホルモン投与後，共に認むべき瓮勤を示 さなかつた（図8，9）。

\section{考案}

従来, 生理的な Insulin 分泌の調節は, 過血糖 若しくは苹局所を潅流する血中のブドウ糖の濃度 によつて綜体液性に行なわれ，神経性の調節機構 はたとえそ礼が存在するとしても，二次的な意 義を有するに過ぎないとされていた。こ〉に著者 が特に考案を加えようとするInsulin 分泌の神経 性調節の問題は，これを検索する目的で行なわれ て来た促来の実験方式が，主として，睐と神経と の連絡を完全に迬断した動物（移植萃動物）或い は特定な神経を切断乃至薬物的に遮断した動物の 空腹時血糖值の变動，若しくは粕同化曲線の様相 を㭘討するものてあり，斯くして得られた成續か ら, Insulin 分速の神経性調節乃全将特定の神経 によるInsulin 分泌支配の問題が論じられてい た6〜位. しかし，このような検索方式の基盤とな つた見解, なかんずく Insulin 分泌六進の直接 刺激は過血糖であり,糖同化曲線は, 稦負荷後の過 血楉により惹起された Insulin 分泌充進によって 規定される」云う見解が，極めて疑䣡の多いもの である事は, 既に当教室の葛谷，小坂らがしばしば 指摘して来たところで西る15)。即ち小坂らは，急

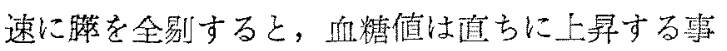
なく, 剔蓕後も数時間に亘り正常值に維持される 焉を知り，更にこの狀態における経口及び静脈内 貧荷に上る糖同化曲線の様相を検討し，剔荤前と 何らの差罢を示さないと事を確認した ${ }^{16)}$ 。この成 績は，末梢血糖值及び糖同化曲線が，Insulin 分
泌を全く欠除した狀態にあっても，正常に保持さ れ得る求を明らかにしたものである。故に，右侧 迷走神経の切断により，正常犬に敏常認められる Insulin 分泌穴進の消失した場合においても，そ の烣化曲線が正常犬と差異を示さなかつた本報の 実験成績は，小坂らの成續を追認するものと元え 上う.

小坂は雪に，下垂体副腎髄質剔出ラット法によ り直接膵静脈血中Insulin濃度の变動を䚁察しーブ ドウ糖静脈内投与後 2 時間を最高倠とするInsulin分泌の克進代营起される事を認め，又このInsulin分泌充進は，膵局所の過血糖或は末梢血糖の 上昇によつてもたらされるものでない事を明らか にする成續を得て, Insulin 分泌の直接刺激は， 促来考えられていた如き過血栯そのものではない との見解を表明した3．文最近当教室の吉沢は， ブドウ糖以外に，綜合アミノ酸製剂及び脂肪の投 与も，それぞ特徵あるInsulin 分泌の六准をも たらす事を確認しぬ，Insulin 分泌灾進が，血糖 值の高さそのものではなしに，生体内の物韻代謝 の動きと密接な関係を有するものである事を明ら かにした、灭著者らは，Campbell ら19)が生長木 ルモンを逶日投与してイヌに持続性糖尿病を発症 せしめる事に成功した際の 1 回の注射量 $3 \mathrm{mg} / \mathrm{kg} の$ 生長ホルモンを筋肉内注射した埸合，1ヌの膵静 脈血中 Insulin 濃度は, 著明な上舁を示し,かつ これが長時間持続する事を磪認した5)。生長ホル

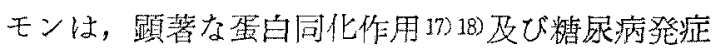
作用 19920)を有する事が知放れて打り，組織に招け る代謝に対し大なる影響を及汪すものとされてい

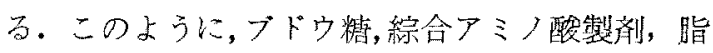
肪及び生長ホルモン等方 Insulin 分泌の艺進を 菭起するのは，これらの物質が投与された事によ り，生体内にもたらされた代謝の進行に伴なうInsulin 需要の增大が，箩しくInsulin 分泌の元隹 （追加的 Insulin 分泌）走うがすも的考古る。

本靬の奏験において，著者は，ブドウ楛，綜合 アミノ酸製戍及び生長ホルモン投与の後に正常犬 に抒いて每常認められる Insulin 分泌元進妨， 
右側迷走神経切断後には，等しく完全に消失する 事，しかし左側迷走神経の切断は特買な影響を与 えない事を確認した。この事実は,ブト゚ウ堵, 綜合 アミノ酸製洲及び生長ホルモン投与により惹起さ れるInsulin 分沙克進の発現には，等しく右迷走 神経が常に健在である事を必要とする繁, 即ち右 迷走神経は, Insulin 分泌の調節機丵において, 極 めて重要な役割を演じている事を明示するものと 考えると同時に，Insulin 分泌光進の遁応刺激と して我乃の提唱する「代謝の進行に伴なうInsulin 需要の增大」令，Insulinの分泌充進をもたらす 為には，右迷走神経が常に健存寸る等を必要と し，又纹神経がこの機構に何らかの形で関与して いる牙を示唆するもの上信じる。

さて, Insulin 分泌に対する迷走神経の調節機 棈に関しては，次の二種類の様式を想定する事が 出来るであろう。

1) Insulin の分泌克進を促す衝動は，右側迷 走神経の興舊によつて下降性に断えずラ氏島 $\beta$ 細 胞に送られる。

2）Insulin 分泌古進を促寸衝蝮は，迷走神経 以外の何らかの機構によつて が，この場合， $\beta$ 細胞が Insulin 多量に放出す る為には右迷走神経が健存する事老必要とする。

これらの想定のいすれをも榬局的に立証し得る 成績は未だ得られていない，しかし著者は，第1 報において，切断した石側迷走神経の末梢側断端 の電気刺激が頙著な一過性の Insulin 分泌克進を 萑起する事策を確認した。この成續は，生本の或 る種の杀件下に起こるInsulin 分泌充推名，右側 迷走神経の興㟢仙よつて，もたらされる可能性を 示惨するものであり，従つて本垠の成綨, 即ち,ブ ドウ糖，䌇合アミノ酸製刘或いは生㫳ホルモン投 与によるInsulin 分湘の亢淮が起こる際に，常時 この右迷走神経の健存加必要とされる事实は，こ

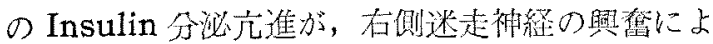
つてもたらされると云う第一の想定, 即占, 右迷 走神経を介する遠心性の機椹に，上り多くの可能 性が存在する寻のと考无る。し加，Insulin 分
泌に対する神経調節機構の全貌を解明するには， 今後更に検討を重文る必要があるものと思う。

\section{結論}

迷走神経の Insulin 分泌調節の生理的意義を検 討する目的で，先に当教室に扔いて確認したフト ウ楉, 綜合アミノ酸製剂及び生長ホルモン投与後 の Insulin 分泌克進に対する迷走神経切断の影響 を，下垂体副腎髄筫剔出ラット法により，イヌの 膵静脈血中 Insulin 潧度の变動を観察する事によ つて檢討し，次の成續を得た。

1）ブドウ糖，綜合アミノ酸製绪及び生長ホル モン投与後に招来される各 Insulin 分泌九進は， 横隔膜直上に扔ける右侧 (背側) 迷走神経の切断 により常に消失した。

2）左侧（腹側）迷走神経切断大は，ブドウ糖 投与後，正常犬と同梯の Insulin 分泌充進を示し た。

以上の成績から，右侧迷走神経は，これらの Insulin 分泌交進の招来に際し不可欠のものであ り, Insulin 分泌調節機棈における重要な意義— 一恐らく該分泌に対し促進的な作用一を有卞るも のと推論される。この問題に関し，若干の考案を 加えた。

（本論交の要旨は，第54回日本内科学会総会及び第 30 回日本内分䟤学会総会に扰いて報告した。)

\section{文献}

1) Kosaka, K., T. Ide \& N. Kuzuya: Endocr. Jap., $4: 248,1957$. - 2) 井出健觉, 小坂樹衡,

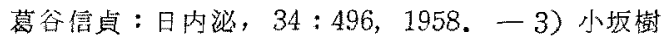
徳, 尾形安三, 石丸安世, 井出健虔, 吉沢国雄, 葛 谷信貞：日内泌, $33: 255,1957,-4)$ 吉沢国䧸： 日内会誌, $48: 837,1959$. 一 5) 茾出健彦, 葛谷信 貞, 小坂柎魚, 尾拒安三, 吉沢国雄, 金東昭雄, 二宫 陸雄, 石溲和男: 日内泌, $34: 593,1958$, 一 - 6) Hedon, E.: Arch. intern. de Phys. $13: 3$, 255, 1913. - 7) Allen, F.M.: J. Metab. Research., 1: 53, 1922. - 8) Banting, F.G. \& S. Gairns: Am. J. Phys. 68:24, 1924. - 9) Houssay, B.A., J. T. Lewis \& V.G. Foglia: Compt. r. Soc. Biol. $100: 140,142$, 144, 1929. Houssay, B.A., V.G. Foglia \& F.S. Symth: J. Exp. Med. $174: 283$, 1941. - 10) Gayet, R.C. \& M. Guillaumie : Co- 
mpt. r. Soc. Biol., $97: 1615$, 1927. ibid. 112: 1194, 1933. - 11) Ernould, H.: Compt. r. Soc. Biol. 103 : 946, 1930. Hoet, J. \& H. Ernould: J. Phys. $70: 1$, 1930. -12 ) Etcheverry, A.O. Compt. r. Soc. Biol. 103 : 946, 1930. ibid. 126, 1937. - 13) Colwell, A.R.: Am. J. Phys., 91: 679, 1930. - 14) Clark, G.A.: J. Phys., 59: 466, 1925. ibid. $61: 576,1926$. ibid. $73: 297$, 1931。一-15) 薯谷信貞, 小坂樹徳, 八川宗一：最 新医学, $8: 61,1953$. 一 16) 小坂樹徳, 尾形安 三，水野美淳，葛谷信貞：ホルモンと臨床， 1：
314, 1953. - 17 ) Gorden, G.S., L.L. Bennett \& C.H. Evans: Endocrinology., $42: 153,1948$. Bennett, L.L., A.P. Applegrath \& C.H. Li: Proc. Soc. Exp. Biol. \& Med., 62 : 42, 1946. - 18) Kochakian, C.D. \& C.E. Stettner: Am. J. Phys. 155 : 255, 1948. - 19) Campbell. J., I.W.F. Davidson, W.D. Snair \& H.P. Lei: Endocrinology, $46: 273$, 1950. Campbell. J., H.R. Hausler, J.S. Munroe \& J.W.F. Davidson: ibid. $53: 135$, 1953. - 20) Li. C.H., B. Kalman \& H.M. Evans: Arch. Bioch., $22: 357,1949$. 